\title{
Age-related changes in testicular parameters and their relationship to thyroid hormones and testosterone in male Murrah buffaloes
}

\author{
Vyankat Gangadhar Jadhav, Bagepalli Sathyanarayana Bharath Kumar, and Sujata Pandita \\ Animal Physiology Division, ICAR-National Dairy Research Institute, Karnal, India
}

Correspondence: Bagepalli Sathyanarayana Bharath Kumar (bharath.kumar.vet@gmail.com)

Received: 3 February 2018 - Revised: 16 April 2018 - Accepted: 23 April 2018 - Published: 8 May 2018

\begin{abstract}
The present study aims to investigate the age-related changes in testicular parameters and their association with plasma triiodothyronine $\left(\mathrm{T}_{3}\right)$, thyroxine $\left(\mathrm{T}_{4}\right)$, and testosterone in male Murrah buffaloes. Testicular measurements and single blood samples were collected from male Murrah buffaloes $(n=103)$ aged between 6 months and 8 years. The correlation coefficients of average testicular length (ATL), paired testis width (PTW), and scrotal circumference (SC) in relation to age were $0.88,0.91$, and 0.90 , respectively. The regression equation between testicular weight (TW) and age was $Y=1.48 \times x^{0.005}\left(r=0.90 ; R^{2}=0.79\right)$. Plasma $\mathrm{T}_{4}$ and testosterone increased significantly $(p<0.001)$ with age and their levels ranged between 12.9 and 41.8 and 0.05 and $1.48 \mathrm{ng} \mathrm{mL}^{-1}$, respectively. With respect to associations between testicular parameters and plasma hormone levels, we observed significant $(p<0.01)$ correlations between ATL, PTW, SC, TW, and plasma T4. A significant correlation $(r=0.31 ; p<0.01)$ between plasma $\mathrm{T}_{4}$ and testosterone levels was also observed. However, the correlations between plasma $T_{3}$ and testicular parameters and plasma $T_{3}$ and testosterone were non-significant. From the present study, we conclude that plasma $T_{4}$ is positively correlated with testicular parameters and plasma testosterone, indicating its role in testis development and steroidogenesis.
\end{abstract}

\section{Introduction}

Bull fertility is an important aspect because one bull may serve around 20 females under natural conditions or hundreds of thousands under an artificial insemination program (Devkota et al., 2011). Reliable fertility information can be obtained on several bulls by using them to impregnate a large number of cows or by evaluating their semen quality. However, these assessments are time consuming and require the necessary equipment and skills. The inadequacies of these techniques has compelled researchers to identify simple and reliable parameters to predict sperm output and fertility. Testicular weight is one among such parameters that provides an accurate estimate of the amount of sperm-producing parenchyma in the testis (Amann and Almquist, 1962; Coulter and Foote, 1977). In live bulls, testicular weight could be derived by indirect measurements such as testicular length and width and scrotal circumference (Bailey et al., 1998).
Thyroid hormones are critical regulators of growth, development, and metabolism in virtually all tissues, and altered thyroid status affects many organs and systems. For a long period of time, testis was regarded as an organ unresponsive to thyroid hormones (Wagner et al., 2008). However, recent studies have demonstrated its role in testicular development and function. The active thyroid hormone receptor isoforms (TR $\alpha 1$ and $\mathrm{TR} \beta 1$ ) are present in Sertoli, Leydig, peritubular, and germ cells of testis (Buzzard, 2000; Canale et al., 2001; Rao et al., 2003). Thyroid hormone inhibits the proliferation and stimulates the differentiation of immature Sertoli cells during the post-natal period (Matta et al., 2002; Jansen et al., 2007). It also inhibits the proliferation of mesenchymal Leydig cell precursors and promotes the formation of adult Leydig cells (Teerds et al., 1998; Ariyaratne et al., 2000). Triiodothyronine increases the basal as well as LH (luteinizing hormone)-stimulated testosterone production by upregulating the enzymes involved in the conversion of cholesterol to testosterone (Maran et al., 2000; Manna et al., 2001). 


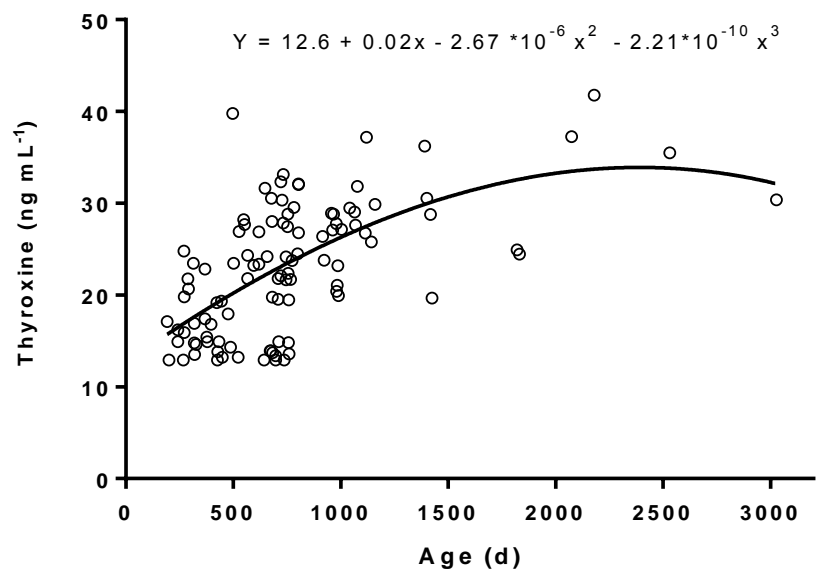

Figure 1. Age-related variations in plasma thyroxine concentrations in male Murrah buffaloes $(n=103)$.

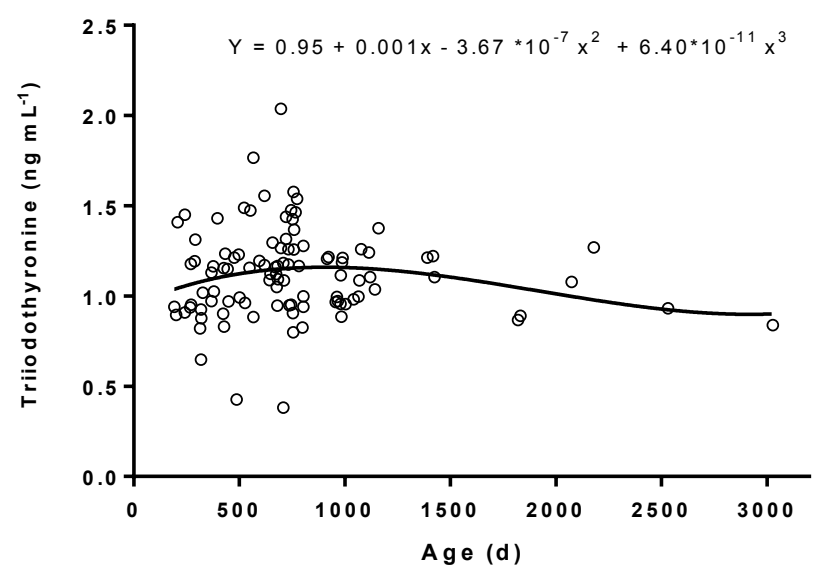

Figure 2. Age-related variations in plasma triiodothyronine concentrations in male Murrah buffaloes $(n=103)$.

Although the literature indicates the involvement of thyroid hormones in the development of testis and the production of testosterone, very few in vivo studies have been conducted to determine their association. With this perspective, the present study was designed to investigate the developmental changes in testicular parameter and its association with thyroid hormones and testosterone in male Murrah buffaloes.

\section{Material and methods}

\subsection{Location of the study and details of environmental variables}

The study was conducted at the Livestock Research Centre and the Artificial Breeding Complex of National Dairy Research Institute (ICAR-NDRI), Karnal, India. The Institute is situated at an altitude of $250 \mathrm{~m}$ above mean sea level, latitude and longitude being $29^{\circ} 42^{\prime \prime} \mathrm{N}$ and $79^{\circ} 54^{\prime \prime} \mathrm{E}$, respec-

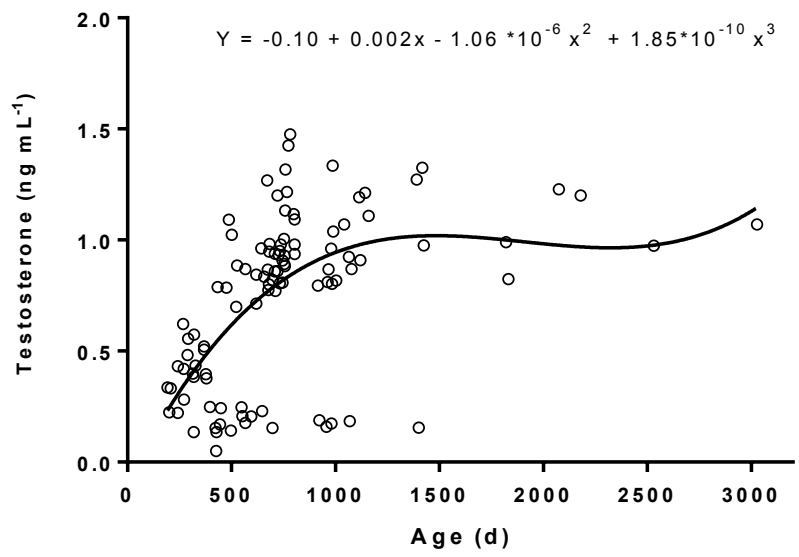

Figure 3. Age-related variations in plasma testosterone concentrations in male Murrah buffaloes $(n=103)$.

tively. During the experimental period, the monthly average temperature and relative humidity fluctuated between 19.3 and $30.3{ }^{\circ} \mathrm{C}$ and 47 and $94 \%$, respectively.

\subsection{Experimental animals, blood sampling, and testicular measurements}

In order to observe the age-related changes in plasma testosterone and thyroid hormones, male Murrah buffaloes $(n=103)$ aged between 6 months and 8 years were selected. Single blood sample was collected from each buffalo in sterile heparinized vacutainer tubes by jugular venepuncture. Immediately after blood collection, the samples were centrifuged at $1077 \mathrm{~g}$ for $15 \mathrm{~min}$ at $4{ }^{\circ} \mathrm{C}$, and the plasma samples were stored at $-20^{\circ} \mathrm{C}$ until they were analysed for hormones. Prior to blood sampling, testicular parameters were measured for each male Murrah buffalo. Scrotal circumference (SC) of the testis was measured with a metal scrotal tape calibrated in centimetres. The length and width of each testis were measured using calipers. The weight of each testis of a pair (TW) was calculated by the formula: $\mathrm{TW}=0.5533(L)(W)^{2}$, where $L$ is length and $W$ is width of the testis (Bailey et al., 1998). Animal experimentation methods were approved by the Institutional Animal Ethical Committee of ICAR-National Dairy Research Institute (1705/GO/ac/13/CPCSEA Dt. 3/7/2013).

\subsection{Hormone assays and statistical analysis}

Plasma testosterone concentrations were determined using a bovine testosterone ELISA kit (MBS704341; MyBioSource, Inc., San Diego, California, USA). Plasma triiodothyronine $\left(\mathrm{T}_{3}\right.$; CEA453Ge) and thyroxine $\left(\mathrm{T}_{4}\right.$; CEA452Ge) concentrations were determined using multi-species ELISA kits obtained from USCN Life Science, Inc., Wuhan, China. The sensitivity levels of testosterone, $\mathrm{T}_{3}$, and $\mathrm{T}_{4}$ assays were $0.05,0.047$, and $1.42 \mathrm{ng} \mathrm{mL}^{-1}$, respectively. The intra-assay 


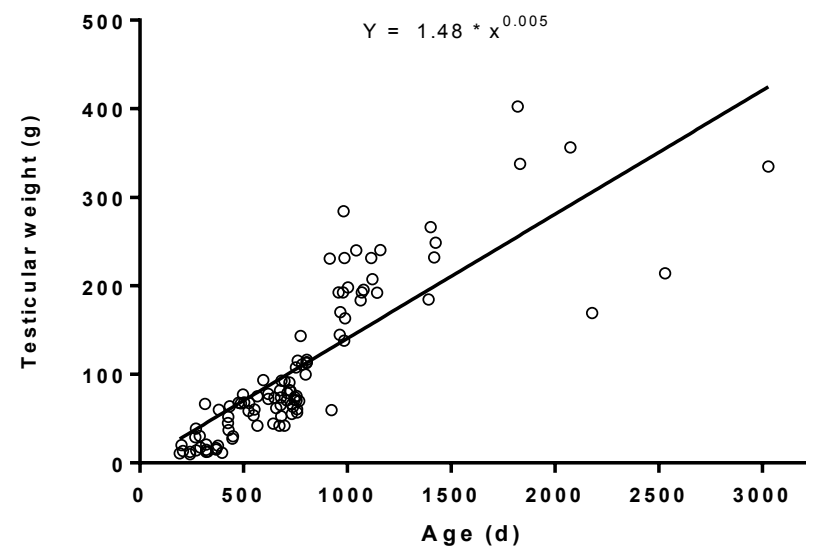

Figure 4. Age-related distribution of average testicular weight in male Murrah buffaloes $(n=103)$.

Table 1. Pearson's correlation between testosterone (T), thyroxine $\left(\mathrm{T}_{4}\right)$, triiodothyronine $\left(\mathrm{T}_{3}\right)$, average testes length (ATL), paired testes width (PTW), scrotal circumference (SC), and testicular weight (TW) in male Murrah buffaloes.

\begin{tabular}{lrrrrrr}
\hline & $\mathrm{T}$ & $\mathrm{T}_{4}$ & $\mathrm{~T}_{3}$ & ATL & PTW & $\mathrm{SC}$ \\
\hline $\mathrm{T}_{4}$ & $0.31^{*}$ & & & & & \\
$\mathrm{~T}_{3}$ & 0.13 & 0.01 & & & & \\
ATL & $0.45^{*}$ & $0.50^{*}$ & -0.08 & & & \\
PTW & $0.51^{*}$ & $0.61^{*}$ & -0.04 & $0.92^{*}$ & & \\
SC & $0.49^{*}$ & $0.58^{*}$ & -0.03 & $0.91^{*}$ & $0.96^{*}$ & \\
TW & $0.40^{*}$ & $0.53^{*}$ & -0.10 & $0.91^{*}$ & $0.95^{*}$ & $0.89^{*}$ \\
\hline
\end{tabular}

* Superscript denotes significant correlations $(p<0.01)$.

coefficients of variation for testosterone, $\mathrm{T}_{3}$, and $\mathrm{T}_{4}$ were 3.4, 5.6, and $4.0 \%$, respectively. The inter-assay coefficients of variation for testosterone, $\mathrm{T}_{3}$, and $\mathrm{T}_{4}$ were $5.9,7.2$, and $6.5 \%$, respectively. Age-related changes in plasma testosterone, $\mathrm{T}_{3}, \mathrm{~T}_{4}$, and testicular parameters were analysed by different regression models. The model that gave the highest $R^{2}$ was chosen to correlate each of the parameters with age and to draw the regression trend line. Pearson's correlation was used to determine the association between thyroid hormones, testosterone, and testicular parameters. GraphPad prism (version 7) and SPPS (version 16) softwares were used for statistical analysis.

\section{Results and discussion}

The plasma concentrations of $\mathrm{T}_{4}$ and $\mathrm{T}_{3}$ and their trend lines in relation to age are represented in Figs. 1 and 2, respectively. The plasma $T_{3}$ and $T_{4}$ levels ranged between 0.38 and 2.04 and 12.9 and $41.8 \mathrm{ng} \mathrm{mL}^{-1}$, respectively. The regression equation between $\mathrm{T}_{4}$ concentrations and age was $Y=12.6+0.02 x-2.67 \times 10^{-6} x^{2}-2.21 \times 10^{-10} x^{3}(r=0.61$; $R^{2}=0.37$ ). The regression equation between $\mathrm{T}_{3}$ concentra- (a)

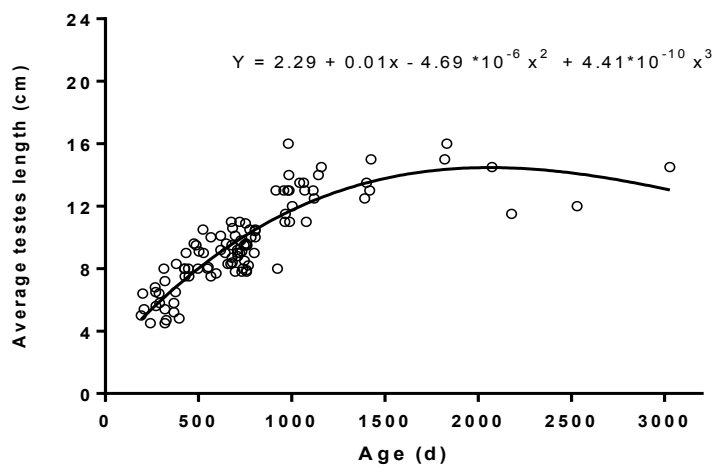

(b)

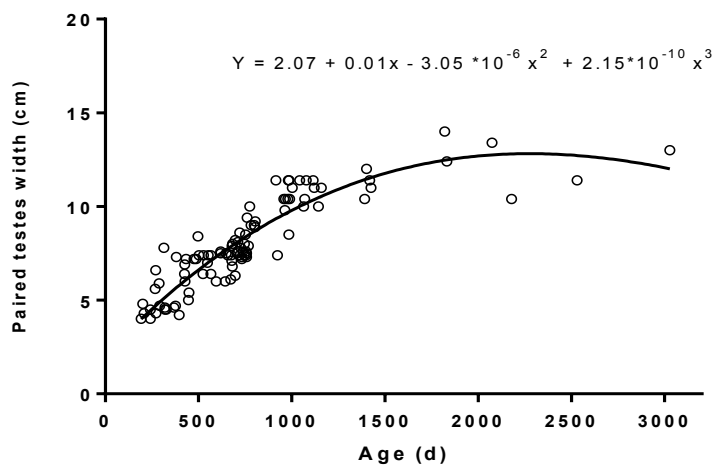

(c)

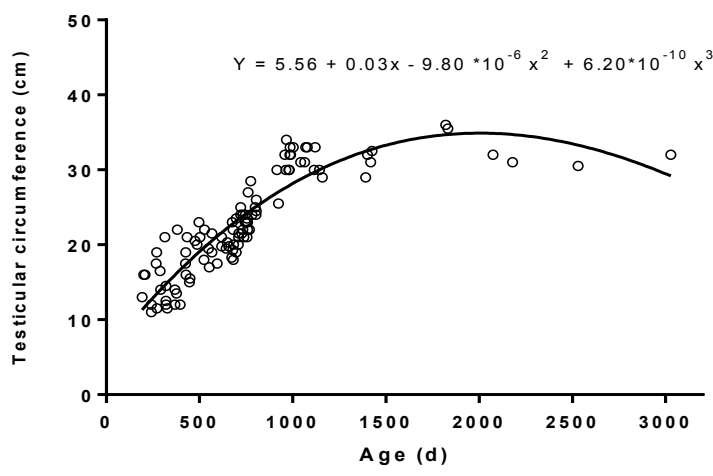

Figure 5. Age-related distribution of average testes length (a), paired testes width (b), and scrotal circumference (c) in male Murrah buffaloes $(n=103)$.

tions and age was $Y=0.95+0.001 x-3.67 \times 10^{-7} x^{2}+6.40 \times$ $10^{-11} x^{3}\left(r=0.2 ; R^{2}=0.04\right)$. The results indicated a moderate relation between $\mathrm{T}_{4}$ concentrations and age, whereas a poor relation between $T_{3}$ concentrations and age was observed. We did not observe a definite trend line of increase or decrease in plasma $T_{3}$ levels with age, which was in agreement with a previous study conducted on Murrah buffaloes (Pandita et al., 2016).

We observed a significant $(p<0.001)$ increase in plasma testosterone with age and its levels ranged between 0.05 and $1.48 \mathrm{ng} \mathrm{mL}^{-1}$ (Fig. 3). The regression equa- 
tion between testosterone concentrations and age was $Y=$ $-0.10+0.002 x-1.06 \times 10^{-6} x^{2}+1.85 \times 10^{-10} x^{3}(r=0.58$, $\left.R^{2}=0.34\right)$. The age-related changes in testosterone concentrations, range of testosterone, and the correlation coefficient value observed in the present study were in accordance with a similar study carried out on male Murrah buffaloes (Gulia et al., 2010). A linear relation in plasma testosterone with age was observed among the animals aged between 192 and 708 days. Similar changes in plasma testosterone were also noticed in investigations conducted on Egyptian buffalo bulls (Hemeida et al., 1985), Angus bull calves (Moura et al., 2001), Angus and Angus $\times$ Charolais bull calves (Brito et al., 2007), and Japanese Black bull calves (Kawate et al., 2011).

The average TW in relation to age ranged between 9.86 and $403 \mathrm{~g}$ (Fig. 4). The regression equation between average TW and age was $Y=1.48 \times x^{0.005}\left(r=0.90 ; R^{2}=0.79\right)$. The dispersion of testicular length, width, and circumference in relation to age and their regression equations are depicted in Fig. 5. The average testicular length (ATL), paired testicular width (PTW), and SC in relation to age ranged between 4.50 and 16.0, 4.00 and 14.0 , and 11.0 and $36.0 \mathrm{~cm}$, respectively. The correlation coefficients of ATL, PTW, and $\mathrm{SC}$ in relation to age were $0.88,0.91$, and 0.90 , respectively. A similar positive correlation of testicular measurements and indices with age was also observed in Holstein (Coulter et al., 1975; Coulter and Foote, 1976), Angus (Coulter et al., 1975; Coulter and Keller, 1982), Hereford (Coulter and Keller, 1982; Menegassi et al., 2011), Charolias (Menegassi et al., 2011), Sahiwal (Ahmad et al., 2011), and Murrah buffalo (da Luz et al., 2013) males. The age-related distribution of testicular parameters (Fig. 5) observed in the present study agrees with the findings of a previous study (Coulter et al., 1975), which inferred that testicular size increases rapidly in young bulls and more gradually in mature bulls.

The associations between testicular parameters, plasma testosterone, $T_{3}$, and $T_{4}$ are given in Table 1 . We observed significant $(p<0.01)$ correlations between plasma $\mathrm{T}_{4}$ and testicular parameters. A significant correlation $(r=0.31$; $p<0.01)$ between plasma $\mathrm{T}_{4}$ and testosterone levels was also observed. However, the correlations between plasma $T_{3}$ and testicular parameters and plasma $\mathrm{T}_{3}$ and testosterone were non-significant. Although $\mathrm{T}_{3}$ is the bioactive form that exerts the developmental (Ariyaratne et al., 2000; Jansen et al., 2007) and steroidogenic effects (Maran et al., 2000; Manna et al., 2001) on testicular tissue, $T_{4}$ also participates directly in testicular development by promoting amino acid accumulation in Sertoli cells (Menegaz et al., 2006). Moreover, most of the $\mathrm{T}_{4}$ is converted to $\mathrm{T}_{3}$ in the testicular tissue. The deiodinases (D1 and D2) involved in the conversion of $\mathrm{T}_{4}$ to $\mathrm{T}_{3}$ are expressed in testis from weanling to adult life (Bates et al., 1999).

\section{Conclusion}

From the present study, we conclude that plasma $\mathrm{T}_{4}$ levels are positively correlated with testicular parameters and plasma testosterone, indicating the developmental and steroidogenic effects of thyroid hormones on the testis.

Data availability. Data are available from the corresponding author upon request.

Author contributions. BSBK and SP designed the experiment, analysed the data, and drafted the manuscript. VGJ and BSBK performed blood sampling, measured testicular parameters, and conducted laboratory analysis.

Competing interests. The authors declare that they have no conflict of interest.

Acknowledgements. Financial support provided by the Director, ICAR-National Dairy Research Institute, Karnal, India, is greatly acknowledged. The authors thank Anand Kumar Nagaleekar, Maher Singh, and Sonu Pal for their manual and technical assistance.

Edited by: Manfred Mielenz

Reviewed by: Smrutirekha Mallick and one anonymous referee

\section{References}

Ahmad, E., Ahmad, N., Naseer, Z., Aleem, M., Khan, M. S., Ashiq, M., and Younis, M.: Relationship of age to body weight, scrotal circumference, testicular ultrasonograms, and semen quality in Sahiwal bulls, Trop. Anim. Health Prod., 43, 159-164, 2011.

Amann, R. P. and Almquist, J. O.: Reproductive Capacity of Dairy Bulls: VIII. Direct and Indirect Measurement of Testicular Sperm Production, J. Dairy Sci., 45, 774-781, 1962.

Ariyaratne, H. B., Mendis-Handagama, S. M., and Mason, J. I.: Effects of triiodothyronine on testicular interstitial cells and androgen secretory capacity of the prepubertal Rat, Biol. Reprod., 63, 493-502, 2000.

Bailey, T. L., Hudson, R. S., Powe, T. A., Riddell, M. G., Wolfe, D. F., and Carson, R. L.: Caliper and ultrasonographic measurements of bovine testicles and a mathematical formula for determining testicular volume and weight in vivo, Theriogenology, 49, 581-594, 1998.

Bates, J. M., St. Germain, D. L., and Galton, V. A.: Expression profiles of the three iodothyronine deiodinases, D1, D2, and D3, in the developing rat, Endocrinol., 140, 844-851, 1999.

Brito, L. F. C., Barth, A. D., Rawlings, N. C., Wilde, R. E., Crews Jr., D. H., Mir, P. S., and Kastelic, J. P.: Effect of improved nutrition during calfhood on serum metabolic hormones, gonadotropins, and testosterone concentrations, and on testicular development in bulls, Domest. Anim. Endocrinol., 33, 460-469, 2007. 
Buzzard, J. J.: Developmental Expression of Thyroid Hormone Receptors in the Rat Testis, Biol. Reprod., 62, 664-669, 2000.

Canale, D., Agostini, M., Giorgilli, G., Caglieresi, C., Scartabelli, G., Nardini, V., Jannini, E. A., Martino, E., Pinchera, A., and Macchia, E.: Thyroid hormone receptors in neonatal, prepubertal, and adult rat testis, J. Androl., 22, 284-288, 2001.

Coulter, G. H. and Foote, R. H.: Relationship of testicular weight to age and scrotal circumference of Holstein bulls, J. Dairy Sci., 59, 730-732, 1976.

Coulter, G. H. and Foote, R. H.: Bovine testicular measurements as indicators of reproductive performance and their relationship to productive traits in cattle: A Review, Theriogenology, 11, 297311, 1977.

Coulter, G. H. and Keller, D. G.: Scrotal circumference of young beef bulls: Relationship to paired testes weight, effect of breed, and predictability, Can. J. Anim. Sci., 62, 133-139, 1982.

Coulter, G. H., Larson, L. L., and Foote, R. H.: Effect of age on testicular growth and consistency of Holstein and Angus Bulls, J. Anim. Sci., 41, 1383-1389, 1975.

da Luz, P. A. C., Santos, P. R. D. S., Andrighetto, C., Jorge A. M., and de Assis Neto, A. C.: The correlation between age, body weight and testicular parameters in Murrah buffalo bulls raised in Brazil, J. Reprod. Dev. 59, 14-17, 2013.

Devkota, B., Takahashi, K. I., Matsuzaki, S., Matsui, M., Miyamoto, A., Yamagishi, N., Osawa, T., Hashizume, T., Izaike, Y., and Miyake, Y. I.: Basal levels and GnRH-induced responses of peripheral testosterone and estrogen in Holstein bulls with poor semen quality, J. Reprod. Dev., 57, 373-378, 2011.

Gulia, S., Sarkar, M., Kumar, V., Meyer, H. H. D., and Prakash, B. S.: Divergent development of testosterone secretion in male zebu (Bos indicus) and crossbred cattle (Bos indicus $\times$ Bos taurus) and buffaloes (Bubalus bubalis) during growth, Trop. Anim. Health Prod., 42, 1143-1148, 2010.

Hemeida, N. A., el-Baghdady, Y. R., and el-Fadaly, M. A.: Serum profiles of androstenedione, testosterone and $\mathrm{LH}$ from birth through puberty in buffalo bull calves, J. Reprod. Fertil., 74, 311316, 1985.

Jansen, H. T., Kirby, J. D., Cooke, P. S., Arambepola, N., and Iwamoto, G. A.: Impact of neonatal hypothyroidism on reproduction in the male hamster, Mesocricetus auratus, Physiol. Behav., 90, 771-781, 2007.

Kawate, N., Ohnari, A., Pathirana, I. N., Sakase, M., Büllesbach, E. E., Takahashi, M., Inaba, T., and Tamada, H.: Changes in plasma concentrations of insulin-like peptide 3 and testosterone from birth to pubertal age in beef bulls, Theriogenology, 76, 16321638, 2011.
Manna, P. R., Kero, J., Tena-Sempere, M., Pakarinen, P., Stocco, D. M., and Huhtaniemi, I. T.: Assessment of mechanisms of thyroid hormone action in mouse Leydig cells: regulation of the steroidogenic acute regulatory protein, steroidogenesis, and luteinizing hormone receptor function, Endocrinol., 142, 319-331, 2001.

Maran, R. R., Arunakaran, J., and Aruldhas, M. M.: T3 directly stimulates basal and modulates $\mathrm{LH}$ induced testosterone and oestradiol production by rat Leydig cells in vitro, Endocr. J., 47, 417-428, 2000.

Matta, S. L. P., Vilela, D. A. R., Godinho, H. P., and França, L. R.: The goitrogen 6-n-propyl-2-thiouracil (PTU) given during testis development increases Sertoli and germ cell numbers per cyst in fish: The tilapia (Oreochromis niloticus) model, Endocrinol., 143, 970-978, 2002.

Menegassi, S. R. O., Barcellos, J. O. J., Peripolli, V., Pereira, P. R. R. X., Borges, J. B. S., and Lampert, V. D. N.: Measurement of scrotal circumference in beef bulls in Rio Grande do Sul, Arq. Bras. Med. Veterinária e Zootec., 63, 87-93, 2011.

Menegaz, D., Zamoner, A., Royer, C., Leite, L. D., Bortolotto, Z. A., and Silva, F. R. M. B.: Rapid responses to thyroxine in the testis: Active protein synthesis-independent pathway, Mol. Cell Endocrinol., 246, 128-134, 2006.

Moura, A. A. and Erickson, B. H.: Testicular development, histology, and hormone profiles in three yearling angus bulls with spermatogenic arrest, Theriogenology, 55, 1469-1488, 2001.

Pandita, S., Bharath Kumar, B. S., and Mohini, M.: Age-related changes and circadian variations in peripheral levels of thyroid hormones in Murrah buffaloes, Biol. Rhythm Res., 47, 815-821, 2016.

Rao, J. N., Liang, J. Y., Chakraborti, P., and Feng, P.: Effect of thyroid hormone on the development and gene expression of hormone receptors in rat testes in vivo, J. Endocrinol. Invest., 26, 435-443, 2003.

Teerds, K. J., de Rooij, D. G., de Jong, F. H., and van Haaster, L. H.: Development of the adult-type Leydig cell population in the rat is affected by neonatal thyroid hormone levels, Biol. Reprod., 59, 344-350, 1998.

Wagner, M. S., Wajner, S. M., and Maia, A. L.: The role of thyroid hormone in testicular development and function, J. Endocrinol., 199, 351-365, 2008. 